\title{
The Critical Study of Religion and Division in the Age of Covid-19
}

\author{
Jason S. Sexton \\ University of California, Los Angeles, United States \\ jasonsexton@ucla.edu
}

\begin{abstract}
The Covid-19 pandemic presented enormous challenges for secular and religious institutions as well as religion scholars engaged in the critical study of religion. The unique opportunities for scholars of religion include questions about the very nature of our academic work. Inclusive of scholarly research and dissemination, along with the administrative work and service that facilitates this, is academic work to draw from the rich wellspring of the traditions we study and represent, or does it neglect them in the daily affairs of our work? With a particular regional focus, and despite traditional academic disciplinary conventions within the critical study of religion, this article argues that religious traditions and the critical appropriations of their wisdom and ongoing actions provide an important reckoning with the reality of the ever-changing and often terrible conditions in the contemporary world. They provide a critical feature of what it means to cultivate an ecology of ethical responsibility and care.
\end{abstract}

\section{Keywords}

Covid-19 - academic conferences - religious studies - public theology - AAR

\section{Introduction}

When the Covid-19 pandemic hit, religious communities and scholars of religion stood in unique positions to interpret the phenomenon. Nearly every religious tradition contains some accounting of plagues in its history: from the plagues of Egypt written in monotheistic traditions' texts to those that 
occurred in the history of Eastern religious, to those of indigenous traditions, and many others. As such, believers and religion scholars should have not only been less surprised when the plague hit but also more prepared to helpfully address it in meaningful ways.

In interpretive capacity, scholars of religion also play significant roles in contemporary culture. At a formal level, this is seen in ways the last several Presidents of the American Academy of Religion (AAR) recently wielded their platforms to address critical issues of the day. Laurie Zoloth pled with scholars of AAR to be 'interrupted' and moved to action regarding the climate crisis; ${ }^{1}$ Thomas Tweed weighed into divisive debates about the nature of the critical study of religion for the public and higher education; ${ }^{2}$ Eddie Glauge pressed the importance of a liberal education, including the study of religion, in the Trump era; 3 David Gushee lamented and repented of the contribution of white evangelicals to racism, white supremacy, and Trumpism; ${ }^{4}$ and Laurie Patton reflected on the nature of religion amid contingencies within higher education and the discipline, proclaiming the dynamic role of religion as a public resource. ${ }^{5}$ Presidents of the AAR have the opportunity to speak prophetically with regard to critical contemporary issues. Each of the addresses above, later published in the Journal of the American Academy of Religion, which some claim to be the high-water mark of serious critical scholarship on religion, dealt with matters at the national level (or international, to some degree), harnessing AAR's significant voice as a collective organization to speak to matters of great cultural relevance to our institutions and daily lives.

Matters are slightly different within the AAR regions: they boast significantly smaller numbers than the national AAR conference and represent only

1 Laurie Zoloth, '2014 AAR Presidential Address: Interrupting Your Life: An Ethics for the Coming Storm', Journal of the American Academy of Religion, 84:1 (2016), 3-24, <https://doi .org/10.1093/jaarel/lfvo93>.

2 Thomas A. Tweed, 'Valuing the Study of Religion: Improving Difficult Dialogues Within and Beyond the AAR's "Big Tent", Journal of the American Academy of Religion, 84:2 (2016), 287322, <https://doi.org/10.1093/jaarel/lfwo19>.

3 Eddie S. Glauge, Jr. '2017 AAR Presidential Address: A Liberal Arts Education in the Age of Trump', Journal of the American Academy of Religion, 86:2 (2018), 297-306, <https://doi .org/10.1093/jaarel/lfyoo3>.

4 David P. Gushee, '2018 AAR Presidential Address: In the Ruins of White Evangelicalism: Interpreting a Compromised Christian Tradition through the Witness of African American Literature', Journal of the American Academy of Religion, 87:1 (2019), 1-17, <https://doi .org/10.1093/jaarel/lfzoo4>.

5 Laurie L. Patton, '2019 AAR Presidential Address: “And Are We Not of Interest to Each Other?" A Blueprint for the Public Study of Religion', Journal of the American Academy of Religion, 88:3 (2020), 639-63, <https://doi.org/10.1093/jaarel/lfaao44>. 
a portion of the wider AAR membership, often, and unfortunately, sans senior scholars in the region. And yet the regions carry out the mission of the AAR as significant annual gatherings, bringing together scholars and practitioners from ten geographical locales in North America to contribute more locally to AAR's ongoing work. AAR's mission in the regions is stated this way: 'AAR fosters its mission through energetic cultivation of accessible regional intellectual networks and identities to serve members where they live and work, and to respond to local publics and concerns.' ${ }^{6}$ Not entirely dissimilar to AAR's recent emphases, engaging public and social issues, the regions carry a similar task with regard to 'local publics and concerns'.

This has been done with relative effect in the Western Region of the American Academy of Religion (AARWR), which stands as the largest, most diverse region of the AAR - the only region with Black and Queer Caucuses, for example - which is reasonably supported by its regional academic institutions. As public fora, the regional organization's annual presidential addresses carry a similar function to those of the national meetings, although, again, addressing more regionally-focused 'local publics and concerns'. Many matters may be taken up in a regional presidential address. These may range from how one came to the study of religion or academia ${ }^{7}$ through possibilities for the study of religion from the academic fields wherein scholars work and on to the critical role that religion plays in the broader academic disciplines (Arts, Humanities, Sciences). The latter has become especially important as the case for religion/theology has become more hard-pressed than ever: the challenge is seen in the forms of dwindling open positions, AAR members departing the academy, or the all-around struggle not only to be relevant to our departments, institutions, and related publics, but even to exist anywhere in these spheres in the contemporary moment.

As a scholar who studies religion while conscious of my specific locatedness in a particular region (the West, and California) - and a theologian with an explicit research agenda deliberately aimed at addressing matters in and for

6 See 'AAR Regions', <https://www.aarweb.org/AARMBR/About-AAR-/Regions.aspx> [accessed 21 May 2021].

7 Recent personal accounts of the experience of immigration and trauma were brought into conversation with the critical study of religion in Presidential addresses by Buddhist scholar Jonathan H. X. Lee, 'Memory, Genocide, and the Ethics of Identity', unpublished 2018 AARWR Presidential Address, The Institute of Buddhist Studies, Berkeley, California, 24 March 2018, and Islam scholar Abdullahi Gallab, 'Adrift in the Regions of Days and Nights: Thirty Years as a Gentile: Is Religion the Problem?' unpublished 2019 AARWR Presidential Address, Arizona State University, Tempe, Arizona, 2 March 2019. 
the region ${ }^{8}$ - my desire had long been to demonstrate theology's critical role and relationship to current events. During the weeks leading up to the 2020 regional AARWR meeting, which took place 20-22 March, as Covid-19's early effects unfolded, I quickly chose to shift the regional Presidential address from its earlier planned aim..$^{9}$ In turn, I opted to focus on how local communities were affected and responding to the pandemic as the scope of things unraveled. This decision seemed to me to be a consistent with other Presidential addresses, especially at the national level.

Responding to a pandemic is no easy task. In the early days of Covid, institutions otherwise deemed authoritative sent repeatedly mixed messages. In California, these came from the California Department of Health, state officials, and the governor, who gave a directive on 11 March 2020 recommending cancelling gatherings of 250 or more people across the state to combat community spread in a practice called 'social distancing.'10 Governor Gavin Newsom then followed the next morning with an executive order and clarifying comments in a news conference that he 'considers the directive to be mandatory'.1 The inebriating cocktail of confusing information - from local to

8 Expressed in Fred Sanders and Jason S. Sexton, eds., Theology and California: Theological Refractions on California's Culture, (New York: Routledge, 2014) and in my work as Editor of University of California Press-published Boom California, <www.boomcalifornia.com>, engaging California history, culture, and social issues.

9 The presentation initially was to be titled, 'Black Church Resistance and the Future of Black California', addressing the nature of Black church resistance as it relates to the future of California amid California's shrinking Black population spurred by waves of flight, gentrification, and reverse-migration.

10 Taryn Luna and John Myers, 'Large gatherings should be canceled due to coronavirus outbreak, California Gov. Gavin Newsom says', Los Angeles Times, 11 March 2020, <https://www.latimes.com/california/story/2020-03-11/coronavirus-outbreak-large -gatherings-canceled-governor-gavin-newsom-california> [accessed 18 March 2021]. See later challenges to this nomenclature in favor of the term, 'physical distancing' (Cecilia Menjívar, Jacob G. Foster, and Jennie E. Brand, 'Don't call it "social distancing”, $C N N$, 21 March 2020, <https://www.cnn.com/2020/o3/21/opinions/physical-distancing -menjivar-foster-brand/index.html> [accessed 18 March 2021]), highlighting more than just confusing communication from authorities but also in basic prescriptive conduct.

11 John Woolfolk, 'Coronavirus: Gov. Newsom orders statewide cancellation of gatherings over 25o: Ban on large gatherings at least through March', Mercury News, 12 March 2020, <https://www.mercurynews.com/2020/o3/12/coronavirus-gov-new som-says-cancel-gatherings-over-25o-statewide/> [accessed 18 March 2021]. The entire pandemic has increased pressure on California Governor who now faces a 
state to federal (exacerbated by mixed messaging from the White House and the Centers for Disease Control and Prevention) to global agencies like the World Health Organization and experts from other countries - coupled by the spread of viral social media images and an active press trying hard to keep up amid their own challenges, had left many wondering how to proceed: to stay home or not stay home; to buy food at the local Chinese restaurant, supporting local hard-hit businesses and families, or to eat at home; to travel somewhere 'safer' or to not travel at all (expressly relevant for students whose universities were also shutting down), especially if immunocompromised ${ }^{12}$ people reside at one's destination. The toxic brew of information and misinformation served to make decisions even more complex. And the ways that hardened divisions occurred along politically polarized lines further exacerbated the problem, especially because not only did the partisanship end up sacrificing lives, but there has been a plethora of responses to pandemics throughout history where various leaders intentionally opted for people to die rather than tell them the truth and face political reprisal and retribution, not entirely dissimilar to former President Trump's response.

When the pandemic hit, the Los Angeles Times maintained diligent, careful, creative reporting, all of which material on the pandemic was made free to the public and not bound by a pay wall. Yet even their solid journalism quickly avalanched with stories changing considerably from day to day, or hour by hour. The changing narratives made it difficult to trust even the most trusted forms of journalism, which had become one of the few things the public could rely on, although the condition of the new media under Trump had been significantly weakened. Still, leading journalists like Pulitzer-prize-winning reporter Steve Lopez, the Sunday morning of our regional AARWR conference, took aim to highlight not only the great uncertainty of the situation but also that the pandemic would one day pass - a significant matter to be reminded of in a disaster. ${ }^{13}$ This steady future-mindedness is a reminder also supplied by religions and their theologies - specifically, their eschatologies and

recall in large part for his response to the pandemic, which one operative likened to him 'basically trying to govern in the Book of Revelation' (Shawn Hubler, 'A Recall for Newsom in California? Talk Grows as Governors Come Under Attack', New York Times, 24 February 2021, <https://www.nytimes.com/2021/o2/24/us/newsom-recall .html $>$ [accessed 18 March 2021]).

12 Meaning those whose immune systems are already low, affecting the ability for the body to fight off an illness or infection.

13 Steve Lopez, 'Coronavirus and the week that changed everything - for now', Los Angeles Times, 14 March 2020, <https://www.latimes.com/california/story/2020-03-14/lopez -covid19-coronavirus-week-changes $>$ [accessed 18 March 2021]. 
contestable claims about the future. Not a prophet, did Lopez know the plague would pass?

Nevertheless, while met with caution and disregard, with optimism and pessimism, the pandemic hit, and remained, for over a year. Academic institutions closed, as did local schools whose leaders struggled frantically to communicate. ${ }^{14}$ Amusement parks like Disneyland closed for the first time, which was only initially to go through the end of the month the pandemic hit. Again, the optimism, which for Disneyland seemed to be simply just an unfortunate delay to people longing for the 'happiness' induced by The Happiest Place on Earth. ${ }^{15}$ But it was much more than this temporary interruption, with nearby hotel workers, often immigrants who were already struggling for work hours and to pay bills, facing dire scenarios in the midst of the shutdown. ${ }^{16}$

The complexity lingered as sweeping restrictions were put into place, calling for home isolation of residents over age sixty-five, ordering the mandatory closure of all bars, wine bars, breweries and pubs, calling for restaurants to reduce their occupancy by half. ${ }^{17}$ The initial school closures, at least in higher education institutions, seemed to have started in California: a Stanford Medicine faculty member tested positive for the virus and then on 6 March it was announced that classes were moving to finish the academic quarter online. ${ }^{18}$ It appears that most if not all of California's great institutions of higher learning, public and private, ended up going this route. I delivered my final lecture of UCLA's winter quarter in a 150-student course on 12 March via Zoom (the first Zoom lecture), even as all final essays were due the end of the same week with a final exam coming the following Wednesday, leaving students panicked the weekend before the final amid efforts to fly home abroad. They were left wondering if they could adequately prepare for (or even submit) the online final. Irrespective of the stress and pressure, the moves of the universities to

14 The public school my children attend sent nine different emails over two days as things shut down.

15 Joseph Chytry, 'Disney's Design: Imagineering Main Street', Boom: A Journal of California, 2:1 (2012), 33-44, <https://doi.org/10.1525/boom.2012.2.1.33>.

16 Priscella Vega, 'Fans escape reality at Disneyland before it closes. For service workers, uncertainty abounds', Los Angeles Times, 14 March 2020, <https://www.latimes.com/cali fornia/story/2O2O-O3-14/for-tourists-a-last-hurrah-before-disneyland-closes-for-service -workers-outside-the-park-uncertainty> [accessed 18 March 2021].

17 Tony Bizjak, et al. 'Gov. Newsom asks California bars to close, tells older residents to isolate due to coronavirus', Sacramento Bee, 15 March 2020, <https://www.sacbee.com/news/ coronavirus/article241212146.html> [accessed 18 March 2021].

18 Jason Green, 'Stanford cancels in-person classes over coronavirus concerns', Mercury News, 6 March 2020, <https://www.mercurynews.com/2020/03/o6/stanford-cancels-in -person-classes-over-coronavirus-concerns/> [accessed 18 March 2021]. 
socially distance and shut down in-person operations seemed right. An eloquent explanation was given at the early part of the shutdown by Duke ethicist Luke Bretherton, who noted:

While the personal risks to each one of us may be minimal, this precautionary measure is in an effort to contain the distribution of Covid-19 and ensure we do not become unwitting 'community spreaders' within the close knit community of the university as well as in the surrounding region - especially given each of us is likely to be enmeshed in other communities of contact, notably, congregations. The concern is to ensure the medical system here is not overwhelmed by rapidly escalating demand. As such, not meeting in the flesh is an expression of care for the wider community, especially the most vulnerable among us, and a way to facilitate the work of those in the medical system with a direct vocation to care for the sick. It is thereby an expression of a Christian ethic.

At the same time, I have a duty of care to ensure you receive the education you need to fulfill your vocations in as pedagogically robust and accessible manner as possible. Thankfully, though imperfect, these competing goods can be reconciled and fulfilled through virtual, on-line means. ${ }^{19}$

This was the first theological rationale I heard for cancelling face-to-face classes. It would only be the start of over a year-long situation for students who have been marooned all over the world. ${ }^{20}$

\section{Religious Scholars and the Critical Study of Religion in the Pandemic}

The AAR Western Region decided to cancel its annual face-to-face meeting. It had been in the planning for two years. There had been constant conversation with the host institution, Claremont Graduate University; the decision to cancel happened just one week (5 March) before the meeting was to occur. Cancelling the face-to-face gathering cost a lot, effectively undercutting

19 See <https://www.facebook.com/luke.bretherton.71/posts/10157549166706542>, 12 March 2020 [accessed 18 March 2021].

$20 \quad$ Karin Fischer, 'The Stranded: The pandemic hasn't just disrupted international students' college experience. It has marooned them all over the world', The Chronicle of Higher Education, 8 March 2020, <https://www.chronicle.com/article/the-stranded> [accessed 18 March 2021]. 
a major feature that keeps the regional scholarly body alive. It was cancelled against the recommendation of AAR Executive Director Alice Hunt, ${ }^{21}$ against the leadership of the host institution, and even against my dissenting vote as President of our regional body, where I was also joined together with two other dissenting colleagues on our Executive Committee. The nine others voted to cancel. Ultimately, however, those who voted to cancel the in-person meeting were right, and I was wrong. Had we proceeded with our brick-and-mortar in-person conference, it would not have happened. After the Southwest and Southeast regions of the AAR successfully held conferences from 28 February to 1 March, all seven other regional conference cancelled their conferences, including the one scheduled at Princeton Theological Seminary 9-10 March, the week before ours was to meet.

And yet, our regional body did not cancel the conference. We cancelled the face-to-face meeting, but managed to salvage the great majority of the program, missing out on only a few units whose members decided to postpone meeting until 2021 in the Bay Area, or possibly even in another virtual hybrid conference that had yet to determine details at the time. Everyone at the time, of course, was becoming aware of the relative hysteria that would soon come about as people stockpiled to prepare for home isolation during those early pandemic days mid-March 2020, which seemed to be exacerbated by media attention. Nobody had foresight to anticipate an explosion in infection rates once people began to be tested properly or to anticipate the number of deaths as the virus ran its course.

In that decision to cancel the regional AAR conference, nobody drew from rationale found within represented religious traditions. This neglect or oversight now seems problematic, especially given due awareness of the time-tested principles and values found within the represented religious faith traditions. What great tradition has not seen, and tried to alleviate, great pain, suffering, and evil in the world, especially facing catastrophe? Yet the members of our Executive Committee, representing at least a dozen faith traditions, did not draw from them. ${ }^{22}$ Perhaps it was due to fear over deeper division in light of an already intense moment in our world. Some religious traditions represented

21 See Alice Hunt email to AAR members, 6 March 2020, siding with the Centers for Disease Control recommending to not postpone or cancel large events: <https://mailchi.mp/ aarweb.org/update-on-2020-aar-meetings-and-covid-19? $\mathrm{e}=1 \mathrm{~d} 2533 \mathrm{ad} 8 \mathrm{f}>$ [accessed 18 March 2021].

22 As I made this point in the oral delivery of the presidential address, 15 March 2020, one colleague on the AARWR executive committee who also cast a vote against cancelling the conference stated that she had indeed drawn from her tradition in light of the gravity of the decision to either hold or cancel the conference. When the committee voted to 
by members of the committee, including my own, contain not only powerful world-shaping ideas but also long histories of oppression. We were also already overextended, and any strong appropriation from our religious traditions may have proved doubly difficult. Perhaps, however, their appropriation could have conversely led to an openness to wisdom from these traditions as a way of mutual understanding and expansive possibility that could have transferred the committee back into the world of parsimony and mutual respect and care. At the very least, the faiths represented have long traditions of reading and reckoning with reality, and for these reasons might have been consulted with some effect.

This will be an important consideration going forward into the postpandemic era. As William H. McNeil noted,

In any effort to understand what lies ahead, as much as what lies behind, the role of infectious disease cannot properly be left out of consideration. Ingenuity, knowledge, and organization alter but cannot cancel humanity's vulnerability to invasion by parasitic forms of life. Infectious disease which antedated the emergence of humankind will last as long as humanity itself, and will surely remain ... one of the fundamental parameters and determinants of human history. ${ }^{23}$

We know about these epidemic-pandemic diseases and their courses. In recent memory, Ebola from central Africa was followed by avian influenza, jumping to humans in 1997, followed by SARs at the end of 2002, the latter cases first appearing in Guangdong, South China, in what has been called 'the world's manufacturing hub' ${ }^{24}$ While this has implications for the work of my colleagues at UCLA's California Center for Sustainable Communities, exploring ongoingly big ethical questions about what life will look like in post-carbon cities, moving beyond the mass-production era bequeathed by fossil fuel, ${ }^{25}$ of

cancel, amid intense discussion, this colleague took time to draw from her tradition of spirituality through meditation on a walk following the vote.

23 William H. McNeil, Plagues and Peoples, reprint (New York: Anchor Books, 1998), p. 295. I am grateful to Tony Platt for this reference. See also Bryan Walsh, 'The World Is Not Ready for the Next Pandemic', Time, 4 May 2017, <https://time.com/magazine/us/47666o7/may15th-2017-vol-189-no-18-u-s> [accessed 18 March 2021] for an earlier warning about our vulnerability being on 'a hyperconnected planet rife with hyperinfectious diseases.'

24 Mike Davis, 'Mike Davis on Coronavirus: “In a Plague Year", Jacobin, 14 March 2020, $<$ https://jacobinmag.com/2020/o3/mike-davis-coronavirus-outbreak-capitalism-left -international-solidarity $>$ [accessed 18 March 2021].

25 Stephanie Pincetl, Robert Cudd, Eric D. Fournier, Felicia Federico, Hannah Gustafson and Erik Porse, eds. Energy Use in Cities: A Roadmap for Urban Transitions (London: 
relevance also is not just how plagues shape civilizations, ${ }^{26}$ but even the very discourse of our academic disciplines and the cultivation of knowledge.

In light of the possibility of perpetual disruption, and in light of sections of the program that were lost (including sessions on Indigenous Studies, Womanist/Pan-African Studies, Islamic Studies, among others), I wonder what kind of scholarship may have been lost altogether: further, who may we have lost from the collective work of the critical study of religion? And, how had the program proceeding in all its fullness might have otherwise stabilized the work of contributors to the critical study of religion in the initial Covid-19 moment? I wonder also whom might have been left out or lost in attendance as a result of not being able to access our online capabilities, not only because they are no full substitute for face-to-face engagement, but also because these colleagues may have a disability, or lack electronic capabilities, and in place of the regular conference we simply boosted another Silicon Valley innovative whiteguy thing that we're now perpetuating and others are going to follow. In the unique position that AARWR occupies, with recent presidents being important figures in their institutional and disciplinary settings, there is certainly better approaches to be had in light of all of this, especially if drawing from the particular depths and riches of the traditions we both study and represent.

Nevertheless, throughout the course of our salvaged regional AAR online conference, I attended several papers over the course of the weekend, where contributors reflected on their traditions and those they study: from the process and experience of scripturalization to the healing of sexual abuse, from the recovery of ancient religious practices from around the world to relevant considerations from religious architecture. One particular session stood out to me in the 'Religion, Science, and Technology' unit chaired by Melanie Dzugan and Greg Cootsona, themed, 'Shifting Experiences of Space and Time,' which had special importance for how we were experiencing the shifting dynamic of the conference's media. Following the theme of the conference, Mitchel Hickman from California State University, Long Beach noted the 'rights of passage' of role-playing games, which was also very appropriate for our online conference; Toni Batchelli of Peerspace.com highlighted both the ritualistic

Palgrave, 2000); Eric Daniel Fournier, Robert Cudd, Felicia Federico, and Stephanie Pincetl, 'On energy sufficiency and the need for new policies to combat growing inequities in the residential energy sector', Elementa: Science of the Anthropocene 8:1 (2020), 24, $<$ https://doi.org/10.1525/elementa.419/>.

26 Joe Mozingo, 'From the Black Death to AIDS, pandemics have shaped human history. Coronavirus will too', Los Angeles Times, 12 April 2020, <https://www.latimes.com/califor nia/story/2020-04-12/coronavirus-pandemic-black-death-aids-shape-history>, [accessed 18 March 2021]. 
nature of the Silicon Valley as well as the rights of passage (our 2020 conference theme) of entrepreneurship endeavours, which funneled into the proposed AARWR conference theme for the following year, "Religion and Popular Culture'. The research presented was not only relevant for modes of conferencing that would unfold in 2020 and beyond, including the organizational shifts that the larger AAR would assume as a scholarly organization, but they also reflected a shift that our shared humanity would experience.

AAR does not have a definition for humanity, but the various traditions within the wider AAR do, including what constitutes a human being. These are not uncontestable, nor are their attempts to articulate questions and positions on what constitutes the flourishing of human beings. We learned from our plenary speaker Reggie Williams that a failure to affirm the particular Jewishness of Jesus, replaced instead by a white masculine one, meant a sanctioned disregard for bodies that did not reflect a Linnean archetype that became the normative gaze in the West, which has also chosen to objectify other bodies. ${ }^{27} \mathrm{~A}$ similar point was a feature of Eugene Staples's paper in the Psychology, Culture, and Religion unit, reflecting on the challenge Renaissance painters gave to the male gaze and its objectification of the woman. We also learned from Reggie Williams of how the inherited logic led to the interrogation of bodies that did not reflect the ideal body in the West, and especially in America where Liberty and Freedom were aggrandized beyond any notion of equality, virtually guaranteeing while perpetually affirming the ascendancy of white people. ${ }^{28}$ Yet this leads to the area of point where I would like to focus the remaining of this article.

27 Reggie L. Williams, 'Longing for Mayberry -Cultural Ideals as Weapons of Exclusion,' unpublished plenary address of the 2020 American Academy of Religion Western Region, 14 March 2020, <https://youtu.be/oIURVigEWeM>, [accessed 18 March 2021]; Emmanuel Chukwudi Eze, ed. Race and the Enlightenment: A Reader (Malden, MA: Wiley-Blackwell, 1997).

28 This notion has recently been shown to be operative in relationship of eugenic approaches to those with disabilities and also toward so-called 'criminals' in the mass carceral building project, which Jonathan Simon refers to as a distinct 'eugenic logic'. See Laura I. Appleman, 'Deviancy, Dependency, and Disability: The Forgotten History of Eugenics and Mass Incarceration', Duke Law Journal, 68:3 (2018), 417-78; and Jonathan Simon, "The Criminal is to Go Free": The Legacy of Eugenic Thought in Contemporary Judicial Realism About American Criminal Justice', Boston University Law Review, 100:3 (2020), $787-815$. 
Along with some of the frenzied panic and astonishing foolishness seen with toilet paper gouging and stockpiling, the question may be asked: what happens when the actual course of life is disease and death? This is not unprecedented, but happened with the London Cholera outbreak of 1854, with communities quarantined as they started fleeing the city as they had two centuries prior in 1666 with the Great 'bubonic' Plague. Some of this was seen in the AIDS crisis in the early 198 os as well, trying to not only figure out what the disease was but how to manage it. It became common to blame various populations - today Asians ${ }^{29}$ - when these strange plagues emerged, disrupting life as it is known, and abruptly ending lives of those we know, and those we don't know, and perhaps also do not wish to know.

Here is the significance of the critical study of religion for our present moment: whatever the religion, whatever the definition, human beings matter and all human lives matter. They matter in their particularities. They matter when they are healthy and when they are sick. They matter when they are well and when they are not. ${ }^{30}$ They matter when they are seen and when they are unseen. Very early on, the pandemic laid bare deepening economic inequalities, highlighting both the racial and class divide, ${ }^{31}$ but highlighting persistently that in California at least, younger Blacks and Latinos were dying

29 The recent surge in violence and racial aggression against Asians corresponding directly to the Covid-19 pandemic has led to several initiatives designed to directly combat the recent rise of racist hate against Asian-Americans, including Stop AAPI Hate founded by Manjusha P. Kulkarni, Cynthia Choi, and Russell Jeung (<http://stopaapihate.org/>), which documents and seeks to directly address these recent crimes against Asians committed in light of the Covid-19 pandemic.

30 Compare this to the social Darwinian notion of allowing older people to sacrifice themselves in the name of preserving the country and economy, as articulated by the Texas Lieutenant Governor (Molly Hennessy-Fiske, 'Sacrifice the old to help the economy? Texas official's remark prompts backlash', Los Angeles Times, 24 March 2020, <https:// www.latimes.com/world-nation/story/2020-03-24/coronavirus-texas-dan-patrick> [accessed 18 March 2021). See also a critique of capitalism in this regard in Judith Butler, 'Capitalism Has its Limits', Verso Blog, 30 March 2020, <https://www.versobooks.com/ blogs/46o3-capitalism-has-its-limits> [accessed 18 March 2021].

31 Hailey Branson-Potts, Anita Chabria, Andrew J. Campa, and Priscella Vega, 'Pandemic lays bare a racial and class divide', Los Angeles Times, 8 May 2020, <https://enewspaper .latimes.com/infinity/article_share.aspx?guid=8707obf7-86fc-4591-8coc-38fe15c428d8> [accessed 18 March 2021]. 
at higher rates than their white and Asian counterparts. ${ }^{32}$ Ongoingly and at the end of the pandemic in California, Latinos were still dying more than others. ${ }^{33}$

It cannot necessarily be discounted that God speaks within crisis, and even so that God speaks of judgment. ${ }^{34}$ Actions have consequences - both private and public decisions, and private and public actions, have consequences for the collective ongoing life together on this planet. This collective existence means that we cannot be callous to each other in this moment, but must be careful and wise, cautious and kind. A solidarity is shared in humanity, and not just with individual families but in the unity of all of life, and both an interdependence upon one another and in a deep loyalty to past and future generations. ${ }^{35}$ The contingency is real, but so must be the care for and attention to others, which in Christian theology is a reflection of the way of the cross, overcoming fear and breaking through barriers with kindness that demonstrates the foundation of this kind of motivation, which is divine love for the world: an orientation that reaches out in ways that listen to, build up, advocate for, and creatively serve others, including and especially the most vulnerable.

Religions carry other values too, including what Reggie Williams identifies in Dietrich Bonhoeffer's ethic of 'empathic resistance. ${ }^{36}$ They carry ways of addressing the fears with hope grounded by theological perspectives that aid survival approaches. ${ }^{37}$ But religious sensibilities might also loop back into culture for a wider corporate flourishing and away from runaway recklessness. ${ }^{38}$

32 Ben Poston, Tony Barboza, and Alejandra Reyes-Velarde, 'Racially uneven toll also hits the young: COVID-19 is killing the state's Latinos and blacks under 50 at a troubling rate', Los Angeles Times, 25 April 2020, <https://enewspaper.latimes.com/infinity/article_share .aspx?guid=25aea77e-eb12-41a5-9ba8-9ocee6aaeo29 > [accessed 18 March 2021].

33 Rong-Gong Lin, II, “Tremendous heartbreak": L.A. Latinos still dying at high rates, even as COVID-19 eases', Los Angeles Times, 26 February 2021, <https://www.latimes.com/ california/story/2021-02-26/tremendous-heartbreak-l-a-latinos-still-dying-at-very-high -rates-even-as-covid-19-eases> [accessed 18 March 2021].

34 As such, not judgement in any sense of finality or true justice, but rather in the embodied and contextually contingent acts of remedial judgment. Luke Bretherton, Christianity and Contemporary Politics: The Conditions and Possibilities of Faithful Witness, (London: Wiley-Blackwell, 2010), pp. 214-21.

35 Josiah Royce, The Philosophy of Loyalty (Nashville: Vanderbilt University Press, 19o8; reprint 1995), pp. 103-106; Wendell W. Hoffman and Stanley J. Grenz, AIDS: Ministry in the Midst of an Epidemic, (Grand Rapids: Baker, 1990), pp. 169-73.

36 Reggie L. Williams, Bonhoeffer's Black Jesus: Harlem Renaissance Theology and an Ethic of Resistance, (Waco, TX: Baylor University Press, 2014).

37 Valerie A. Miles-Tribble, Change Agent Church in Black Lives Matter Times: Urgency for Action, (Lanham, MD: Lexington/Fortress, 2020).

38 See the account of religion's role in early Hollywood's rediscovery of religion, for example (Kevin Starr, Inventing the Dream: California Through the Progressive Era, [New York: Oxford University Press, 1985], pp. 330-33), although not without collateral damage 
Yet some of the most important religious work happens locally. The congregation my family and I are part of, City Church Long Beach, led by pastors Brenna Rubio and Bill White, offered the following suggestions for the first Sunday morning of Covid-19 lockdown, in what they called the week's spiritual practices.

The pastors asked the congregation to first, 'Get Lost,' opening an invitation to 'ask yourself some questions about what's been going on inside of you, [and] perhaps pray or journal through them.' This counsel included a query into thoughts and feelings - the good, bad, and ugly, and 'What are you noticing in a new way? What are you grateful for in the midst of it all? Do you have any sense of meeting God on the journey?' Second, they asked the congregation to 'Be Found,' encouraging 'a creative way to intentionally connect with someone, perhaps even a 'stranger' (someone you don't know very well), whether in person with good social distancing practices or by phone or video chatting.' This summons was a request to 'Intentionally pay attention to their needs,' and to afterwards ask, 'Were there ways I felt alive during that time? What did I discover about myself? What didn't go so well? If I had to identify one moment when I caught a glimpse of God, what would it be?' And then, finally, the pastors urged congregation members to 'Consider a special gift to help neighbors who are struggling.' Including encouragement to help support people directly, the church set up a new Community Care tab on their list of giving options, ${ }^{39}$ which was created to help neighbors facing shortages of food and supplies or for emergency help for those struggling to make rent or cover childcare given the new circumstances.' Their call concluded with an invitation for those who may themselves need some support, and to let them know what was going on.

Toward an Ecology of Religious Care and Responsibility

The contexts of terrible tragedies like the one caused by Covid-19 provide precisely the spaces wherein scholars of religion and theologians especially should be engaged. They must do so if religious scholarship is to have relevance in the contemporary world. They must also do so for the sake of the audience broadly conceived, for the publics whose concerns we embrace and for whom we wish

brought by the intermingling of Christianity and Hollywood with a white Nordic Jesus (Edward J. Blum and Paul Harvey, The Color of Christ: The Son of God and the Saga of Race in America, [Chapel Hill, NC: University of North California Press, 2012], pp. 186-7).

$39<$ https://citychurchlongbeach.churchcenter.com/giving/to/community-care> [accessed 22 June 2021]. 
to offer insight and perhaps wisdom. What might these questions mean for the wider critical study of religion?

At the very least, it means there are new things to discover and learn about reality, goodness, kindness, care, and the various rationales for these things that can be adopted and adapted. It also means justice with respect to our wider engagement as scholars of religion insofar as religious faith and practices can not only play countercultural roles that creatively do good to others amid major crises, but also insofar as they offer a prophetic critique of a system that has allowed these things to happen, holding leaders accountable and scrutinizing systems amid their colossal failures. There is another side of this coin: religion's power was harnessed to exacerbate division with congregations that refused to heed local, state, and national directives and health warnings, with at least one case in the name of religious freedom being upheld by the Supreme Court in Roman Catholic Diocese of Brooklyn, New York v. Cuomo. ${ }^{40}$

On the systemic failure of national leaders on public health matters during major health tragedies, the late South African activist and theologian Steve de Gruchy reflected on the deaths of 4,00o people from cholera in Zimbabwe late 2008 to early 2009. For his reflection he looked to the mid-nineteenth century cholera outbreak in London, the problem being that there was no proper sewer system and the people of London were sinking in their own shit. ${ }^{41}$ In hindsight, he noted, the great tragedy resulted from the system. This assessment creates an unusual challenge for humanity living in cities with enormous infrastructural challenges for which these cities (like New York, Los Angeles, London, and New Delhi, for instance) were not prepared. Yet those within these cities who suffer most during tragedies are the poor, the elderly, whose care cannot reasonably be handed over to the current infrastructures to care for the economically precarious, or the medically compromised, or the prisoners. ${ }^{42}$

Much remains to be learnt while watching, praying, and acting (in responsible and socially-distanced ways), speaking to one another in these times, and speaking to what is real, and true, and beautiful all the while washing hands and giving thanks for life, recognizing that all of it is a gift of God. In the theological analysis of recent events, considering both the revelatory/apocalyptic and anthropological dimensions, perhaps the pandemic was not only a failure

40 <https://www.supremecourt.gov/opinions/2opdf/2oa87_4g15.pdf> [accessed 22 May 2021].

41 Steve de Gruchy, 'Water and Spirit: Theology in the Time of Cholera', Ecumenical Review, 62:2 (2010), 188-201, <https://doi.org/10.1111/j.1758-6623.2010.00057.X >.

42 Hadar Aviram, 'Bottleneck: The Place of County Jails in California's COVID-19 Correctional Crisis', Hastings Journal of Crime and Punishment, 1 March 2021, <https:// ssrn.com/abstract=3801903> [accessed 18 March 2021]. 
of human systems, but perhaps the matter was beyond natural. Perhaps it was supernatural. ${ }^{43}$ The question cannot immediately be ruled out, even though it entails a more serious question about the very nature of the disaster.

Additional theological questions loom amid tragedy related to the environment, including the question of whether the contingency of the created order, and the very nature of material reality, is safe, kind, and good. Of course, all of our traditions have addressed these questions, and yet inequality persists. ${ }^{44}$ The Covid-19 pandemic has had highly disproportionate effects on people already disadvantaged, including people of colour and, in California, especially Latinos in disadvantaged areas. ${ }^{45}$ For professional scholars in academia, women juggling domestic responsibilities were most disadvantaged and took the hard hits. ${ }^{46}$

Through the pandemic's challenges, however, creative communities responded in imaginative ways. The LG BTQ community took Pride online, and devoted their June parade to supporting the Black Lives Matter protests in the

43 These questions have been asked as other disasters have hit, including the 1755 Lisbon earthquake, for which see the response of John Wesley ('Serious Thoughts Occasioned by The Late Earthquake at Lisbon', in The Works of John Wesley, third edition, vol. 11 [London: Wesleyan Methodist Book Room, 1872], pp. 1-13) and also these: Margaret G. Flowers, Wayne G. McCown, and Douglas R. Cullum, '18th-Century Earthquakes and Apocalyptic Expectations: The Hymns of Charles Wesley', Methodist History, 42:4 (2004), 222-35; Jon Sobrino, 'Another Earthquake', VidyajyotiJournal of Theological Reflection, 65:3 (2001), 1758; and Luiz Mendes-Victor, et al., eds, The 1755 Lisbon Earthquake: Revisited: Geotechnical, Geological and Earthquake Engineering, (Berlin: Springer, 2008). But even in more recent history, the 1918 Spanish Flu disrupted things greatly, including religious gatherings (Gustavo Arellano, 'This isn't the first time a virus caused social panic. The Spanish flu did too', Los Angeles Times, 16 March 2020, <https://www.latimes.com/california/story/2020 -03-16/los-angeles-spanish-flu-coronavirus> [accessed 18 March 2021]), and some have equated cataclysmic events with the most important ingredient for spiritual renewal: Robert Nicholson, 'A Coronavirus Great Awakening?' Wall Street Journal, 26 March 2020, <https://www.wsj.com/articles/a-coronavirus-great-awakening-11585262324> [accessed 18 March 2021].

44 Butler, 'Capitalism Has its Limits.'

45 The California solution to this was to redirect supplies of the Covid-19 vaccines to these areas in order to slow the virus spread and help speed up the economy's reopening. See Luke Money, Soumya Karlamangla, Melissa Healy, and Rong-Gong Lin, II. 2021. 'California thinks it can stop COVID by flooding poor areas with vaccine. Will it work?' Los Angeles Times, 5 March 2021, <https://www.latimes.com/california/story/2021-03-o5/california -is-flooding-hardest-hit-areas-with-vaccines-to-stop-covid-will-the-new-gambit-work> [accessed 18 March 2021].

46 Anna Fazackerley, 'Women's research plummets during lockdown - but articles from men increase', The Guardian, 12 May 2020, <https://www.theguardian.com/education/2020/ may/12/womens-research-plummets-during-lockdown-but-articles-from-men-increase > [accessed 18 March 2021]. 
struggle not just for inclusion but also in solidarity for racial justice. Public efforts to mobilize against racism, injustice, and inequality transformed virtual online spaces, such as the Poor People's Campaign's massive Assembly and Moral March on Washington. ${ }^{47}$ But online efforts, including the events of the entire 2020 election cycle, still resulted in the neglect of some, with powerful people maximizing power while relying on various forms of spirituality that may not draw from the depth of the stabilizing sources of their traditions. This turn of events is dangerous, since it means that perhaps new, hybrid, and even sinister traditions may yet emerge from the reckless appropriations. Even still, the future remains hopeful because sincere, care-ful, well-meaning, and wise appropriations of these traditions will also arise.

This role that religions play today highlights a special, prophetic function, which in particular and local ways can enable a closer awareness of those who both suffer and benefit during tragedy. This is because communities of faith stand in close proximity to those who win and lose in the current systems, while carrying a robust capacity to center those affected most by inequality and injustice, those on the margins. Religion carries power to challenge systems of oppression as well as the very idea of the 'system' metaphor. It can strip away the mechanisms of a system that possesses a capacity to protect those in power who have shirked responsibility in favour of, at best, opportunism or at worst, recklessness, death, and destruction. For religion to reckon with these things, congregational gatherings remain significant. Yet these gatherings remain a privilege, and a manner of being seen together within a local faith community that not all people experience, and many struggled to experience (including the elderly, challenged by technology). Conversely, the voices of religious communities can be recklessly extended, as has also been seen in those utilizing religious freedom to disregard public health concerns given by health and government officials.

So much remains: the current pandemic still has to run through to its abeyance or conclusion. It is not yet clear what will be the short and long-term effects of the vaccine, and who will be most impacted by the current moment. The reality is that many have died and the generation of conspiracy theories has also increased. ${ }^{48}$

47 See <https://www.june2020.org/> [accessed 18 March 2021].

48 See the point made in Terence Keel and Osagie K. Obasogie ('In the Shadows of Whiteness: Race, Religion, and Radicalization in the Time of Pandemics,' Public Forum on Religion and Pandemic, UC Berkeley Center for the Study of Religion, 5 March 2021, <https://bcsr .berkeley.edu/events/in-the-shadows-of-whiteness> [accessed 18 March 2021]), with Keel noting that the resent conspiracy theories surrounding the virus show the failure of public education and government communication. 
The role that the critical study of religion may play here in seeking to foster critical understanding may be seen as simply pragmatic and secular; it may also be seen as an academic field that shares meaningful space with people of faith who are also thinking within and from (and for) their traditions with a newfound vulnerability, openness, and earnestness about conclusions, awaiting eschatological finality while proceeding with great care in the face of the ever-changing landscape. ${ }^{49}$ With religious congregations starting to reconvene in-person face-to-face gatherings, the divisions not only between religious communities but also deeply-seated internally within particular local communities of faith is becoming accentuated. This hearkens back to the debate and problem about whether the religion scholar is a critic or caretaker of a particular tradition..$^{50}$ In light of what has been argued in this article, that question can be extended to ask whether members of the AAR belong to a society of practitioners (in the broadest sense of the term), or to an academic society where no intention is expected of its members to move beyond the ordinary affairs of academic work, from research and dissemination to administrative facilitation of this work amid whatever disruptions may occur.

This is a very difficult place for any academic scholar to be found in the present moment: issues of inequity and injustice weigh so heavily in the wider western culture. The conference, especially, as a particular site of academic engagement and also as a public space, like any public space, is one for people of faith not to hide their faith, but surely to exemplify and expound it. As with any institutional setting, such conferences can be vehicles of a differentiated and multifaceted interdisciplinary public theology. For those situated within the Christian tradition, these spaces become those where one might 'work out [their] own salvation with fear and trembling' (Phil. 2:12) and also to 'love' both God and one's neighbor (Mk 12:30-31).

Other traditions will have their rationale for conference engagement and the role that faith and practice play together there. Some of this attempt at a coherence of faith, ethics, and action, might be seen as awkward (if not infuriating) to scholars who think that religious faith ought not to inform any mode of public or scholarly discourse. Secular-enthusiasts, which seem to exist in diminishing numbers in the AAR, still may prefer the sidelining of any kind

49 See the argument in Linn Marie Tonstad, '(Un)wise Theologians: Systematic Theology in the University', International Journal of Systematic Theology, 22:4 (2020), 494-511, $<$ https://doi.org/10.1111/ijst.12361> that theology is a discipline of failure, incompletion, and foolishness that requires both humility and unmastery.

50 Atalia Omer, 'Rejoinder: On Professor McCutcheon's (Un)Critical Caretaking', Journal of the American Academy of Religion 80:4 (2012), 1083-97, <https://doi.org/10.1093/jaarel/ lfso79>. 
of faith that might serve as an explicitly situated position from which to conduct critical scholarly reflection. AAR has had a checkered history of efforts to sequester theology, attempting to establish a deck clear of theology in order to proceed with a sense of supposedly value-neutral operations. It has done so while simultaneously maintaining a kind of assumed academic profligacy mixed with the waning-capital of religious studies in the modern university and a declining hegemony of the supposed disciplinary 'standards' of critical neutrality.

This kind of posture suggests not that theology done in this way is a matter of calculated hegemonic posturing, but rather as a matter of believers proceeding with integrity in locations and situations where they might 'confess the hope within them', while found also within the settings of common societal structures. ${ }^{51}$ As such, believers within conferences spaces, as in any public spaces, have a moral obligation and a civic duty to think faithfully from within their traditions in order to witness not just an unfolding of a hope within them (and representing to varying degrees the wider religious community's beliefs which are shared), but also to support those from other traditions in their efforts to be holistically engaged. In this way, it is not as though the conference becomes a place to be colonized or for proselytization. It is a site for deep and critical engagement from particular places where scholars find themselves, and as such, a distinctive and discrete site for public theology.

\section{Conclusion}

The AAR has no need to land decisively on the questions raised in this article, although recent addresses from several AAR Presidents and the many statements from AAR's Board of Directors over the last several years ${ }^{52}$ suggest that the organization already has, in spite of the organization's reticence to acknowledge the incorporation of theological knowledge into its ranks. The $J A A R$ continues to be a publication largely averse to publishing scholarly articles focused on theology, even as the critical study of religion continues to wane. It does so even as few scholars can say with relative confidence where the centre of the discipline of the critical study of religion actually lies. It is

51 Jason S. Sexton, 'Confessional Theology in Public Places', International Journal of Public Theology, 10:2 (2016), 234-48, <https://doi.org/10.1163/15697320-12341444>.

$5^{2}$ 'AAR Board Statements', <https://www.aarweb.org/AARMBR/About-AAR-/Board-of-Dir ectors-/Board-Statements> [accessed 18 March 2021]. 
almost certainly not theology, although no definition of theology from AAR leadership appears to be found anywhere either.

Drawing from the rich wellspring of the religious traditions we study and represent could help enormously as scholars of religion face new and ongoing challenges within the spaces of our academic work, as well as in the world. Neglecting them, on the other hand, or misappropriating them and their wisdom can lead to chaos and death. Indeed, neglect or irresponsible appropriation of wisdom traditions leads to a chosen blindness in the pursuit of justice, and neglects a body of knowledge appropriate for interrogating current systems, and for responsibly coming together for mutual understanding and humility. Academic organizations like AAR may very well feel the pull to simply fit in with other neoliberal secular organizations that exist among other professional academic bodies that exercise no real regard for the faith traditions represented within their purview of discourse. These traditions, as such, may be deemed by some scholars who study them as having no real resources or depth or voice to speak into relevant social issues as they arise. But a better response really can and must be given.

Since the Covid-19 situation has befallen everyone (although not everyone equally), the division generated by the pandemic has provided a unique opportunity to come together. But how does a meaningful coming together happen in an ongoingly tense moment exacerbated by a challenging pandemic? Healing wisdom from religious faith traditions comes precisely from the particular spaces within the traditions, operating apart from any secular agenda and certainly not one co-optable by the state. It is squelched if the tradition is obligated to serve an agenda foreign to the life of the religious faith communities we study and participate in. Such a foreign agenda, in fact, forfeits the organic life happening within communities of faith with their rich interpretations of reality and their ongoing and deeply committed forms of care. These faith communities, as such, would in turn stand as woeful critiques of the state and its propensity to otherwise create further division as a result of the state's inability to fully engage with the realities lived and experienced by communities of faith on the ground.

\section{Acknowledgement}

I am grateful to John Erickson, Valerie Miles-Tribble, Reggie Williams, Cristina Rosetti, Andrea Jain, and Adelaida Brown for their helpful comments on earlier versions of this article, delivered originally as the AAR Western Regional presidential address, 22 March $202 \mathrm{O}$. 